\title{
Comparative Evaluation of Zero-till-slit Seed Drill and Combined Tillage and Seeding Equipment in Rice
}

\author{
Mohammad Quasim ${ }^{1}$, A.K. Shrivastava ${ }^{2}$, S.K. Rautaray ${ }^{3}$ and Avinash Kumar Gautam ${ }^{\text {* }}$ \\ ${ }^{1} C A E, I G K V V$, Raipur, India \\ ${ }^{2}$ Department of FMPE, CAE, JNKVV, Jabalpur, India \\ ${ }^{3}$ C. I. A.E., Bhopal, India \\ ${ }^{4}$ Department of FMPE, CAE, JNKVV, Jabalpur, India
}

*Corresponding author

\section{A B S T R A C T}

\begin{tabular}{|l|}
\hline K e y w o r d s \\
$\begin{array}{l}\text { Zero-till-slit seed } \\
\text { drill, Combined } \\
\text { tillage, Seeding } \\
\text { equipment }\end{array}$ \\
\hline Article Info \\
\hline $\begin{array}{l}\text { Accepted: } \\
\text { 04 May } 2019 \\
\text { Available Online: } \\
\text { 10 June } 2019\end{array}$ \\
\hline
\end{tabular}

Design, development and evaluation of zero-till-slit seed drill were carried out in ricewheat crop rotation. The field performance of the zero-till-slit seed drill was evaluated and compared to the combined tillage and seeding equipment, zero-till seed drill, roto-till seed drill, strip-till seed drill and improved conventional seed drill, The field experiment was carried out following the statistically designed slit drill was with split-split-split plot design. The field performance has revealed that the rotary slit cutters designed and used in the developed zero-till-slit seed drill was functioning effectively for opening narrow slits on untilled plot will 50\% standing stubbles and loose straw was able to place seeds precisely untitled straw fields. The results indicated that the zero-till-slit seed drill showed higher field capacity higher, field efficiency, lower fuel consumption, lower percentage of wheel slip and lower cone index compared to the combined tillage and seeding equipment tested in the study. The results have further revealed higher plant emergence, higher plant population at higher rice yields by use of zero-till-slit seed drill compared to the combined tillage and seeding equipment tested in the study.

\section{Introduction}

Conservation Agriculture (CA) has been recognized to be a viable option to aid sustainable agriculture. CA principles have been adapted and there seems to be opportunities for further collaborative researches, synergy and complements (FAO, 2002). FAO (2006) as reported has been actively involved in promoting conservation agriculture especially in developing/emerging economies. Conservation seeders include several variations in row crop drills and planters. These machines included specially designed separate components for soil and crop residue chopping, depth control, soil opening for desired seed placement and seed slit covering partially. In view of above, development of zero-till-slit seed drill has been carried out at (CIAE-ICAR), Bhopal. Development of rotary zero-till-slit seed-drill for seeding on surface covered rice and wheat straws was aimed at to prevent burning of straw in fields as practiced by the farmers. 
The developed zero-till-slit seed drill was evaluated in rice crop and compared to the other tillage and seeding equipment under controlled traffic and random traffic condition.

Guérif et al., (2001) reported the potential yield response where the crop yields with notill was not usually reduced and yields were equivalent/higher compared to those from conventional tillage practices. Rautaray (2007) reported that the effect of tractor wheeling was minimized with the adoption and use of controlled traffic system, such as reduction in the energy spent for soil compacting and smearing effects and attained greater soil uniformity. Riley et al., (1994) reported that conservation tillage was any system that promotes good crop yields while at the same time maintaining soil fertility, minimizing soil and nutrient losses, and saving energy / fuel inputs. Shukla et al., (2003) developed direct drilling machine with notched double disc furrow opener.

The machine was able to performing sowing operation directly without any prior field preparation under clean and standing stubble field condition. It was reported that the draft requirement for operating the machine was $30-40 \%$ lesser than the no-till drill with inverted ' $\mathrm{T}$ ' type furrow openers. Shumba et al., (1989 and 1992) found that reduced or zero tillage appeared to be more promising in Zimbabwe due to shorter growing season, timeliness of sowing, freeing up crop residue for use as mulch and was important to avoid late season drought.. The replacement of moldboard plow tillage with shallow tine tillage required only $14 \%$ of the draft power requirement of the former and resulted in lower soil disturbance. However, frequent constraint with tine tillage has increased weed competition and weeding requirements. Solie and Pepper (1989) evaluated the ability of four grain drills, equipped with different types of furrow openers and press wheels in Oklahoma, USA. The higher plant emergence and yield were obtained for the hoe-type drill with split V press wheels, although the yield by use of the drill with the double- disc opener and narrow press wheel equaled to that for the hoe drill using a split V press wheel at few locations.

\section{Materials and Methods}

\section{Design, development and fabrication of rotary zero-till-slit seed drill (combined tillage and seeding equipment)}

The tractor operated controlled traffic rotary zero-till-slit seed drill was designed with drawings of the components developed and fabricated for zero-till seeding in straw fields after grain combining. Development of rotary zero-till-slit seed drill was carried out for combined tillage and seeding operation while conserving soil moisture in-situ (Figure 1). The tillage and seeding machine was equipped with seven units of slit cutters mounted on a common shaft for cutting the surface straw / stubbles and opening the narrow and shallow depth slits (Figure 2).

The primary openers were able to open slits having width and depth of $10 \mathrm{~mm}$ and 100 $\mathrm{mm}$ respectively. Secondary furrow openers of seed drill have followed behind the slit openers were for placing seed and fertilizer into the slit made in the soil. The rotary cutters were powered by tractor p. t. o. and metering of seeds behind the slits was through fluted roller mechanism powered by the ground drive wheel of the machine. The main function of the eight spring loaded press wheels were to press-hold the loose straw for smooth cutting (Figure 1). Spring loaded press wheels were positioned at both sides of each rotary cutter unit which was mounted to the main frame at the front end. 
Field evaluation of rotary zero-till-slit seed drill (combined tillage and seeding equipment)

Developed rotary zero-till-slit seed drill with controlled traffic and random traffic condition were evaluated for direct seeding in straw fields. Field experiments were conducted in statistical designed plots to evaluate the drill with other combined tillage cum seeding equipment tested. The observations on field condition, crop parameters and machine performance were recorded.

Details of combined tillage and seeding equipment used for comparative evaluation in field experiment

Zero-till-slit seed cum fertilizer drill zero-till seed cum fertilizer drill, roto-till seed cum fertilizer drill, strip-till seed cum fertilizer drill and conventional seed cum fertilizer drill was evaluated for dry seeding and compared of rice. Brief specifications of the direct drilling equipment are given in Table 1 .

\section{Zero-till seed cum fertilizer drill}

The zero-till seed cum fertilizer drill was used for direct seeding of rice without tillage especially under high moisture condition of the soil (Figure 3). Furrow openers used in the drill were inverted ' $\mathrm{T}$ ' type which opens narrow furrows for placement of seeds and fertilizer.

\section{Roto-till seed cum fertilizer drill}

The roto till seed cum fertilizer drill was used for direct seeding of rice with reduced tillage while chopping the surface straw by single pass of rotavator (Figure 4). The machine was to work under friable moisture condition of the soil. The furrow openers used were of shoe type.

\section{Strip-till seed cum fertilizer drill}

The strip-till seed cum fertilizer drill was used for direct seeding with minimum tillage only in strips (Figure 5). The tillage operation was performed by single pass of rotary blades in strips. It was used with no preparatory tillage. The furrow openers used were of the shoe type.

\section{Conventional seed cum fertilizer}

The improved seed cum fertilizer drill was used for sowing of seeds in the field prepared by conventional tillage implements as per the field condition (Figure 6). The shovel or shoe type of furrow openers were used depending on crop to be sown, soil and moisture condition of field.

Statistical design of field experiments for evaluation of combined tillage and seeding equipment

Studies on performance of combined tillage and seeding equipment were conducted in split-split-split plot design for rice (Kharif 2007 and 2008). The details of main treatment and sub treatments were given as below.

\section{Independent variables}

\section{Main plot: Field condition}

S: Straw condition

WS: Without straw

Sub plots: $\quad$ Tillage cum $\quad$ seeding equipment

(i) ZT: Zero - tillage seeding (Linear inverted T- type opener)

(ii) ST: Slit - tillage seeding (Rotary: trapezoidal, cutter blades for slits in strips)

(iii) RT: Rotary tillage seeding (Rotary: L shaped blade in full coverage)

(iv) SPT: Strip tillage seeding (Rotary: L shaped blades in strips) 
(v) CT: Conventional tillage (three passes) + seeding

Sub - sub plots control traffic condition

(i) WA : Wheeled area

(ii) NWA : Non - wheeled area

Sub - sub -sub plots: Irrigation condition

(i) I : Irrigated

(ii) $\mathrm{D}:$ Dry

\section{Dependent variables}

Working width of sowing, $\mathrm{cm}$

Depth of operation, $\mathrm{mm}$

Speed of operation, $\mathrm{km} / \mathrm{h}$

Actual field capacity, ha/h

Field efficiency, \%

Fuel consumption, $1 / \mathrm{h}$

Wheel slip, \%

Cone index, $\mathrm{kPa}$

Plant emergence at15 DAS, no/m-sq

Plant population at 35 DAS (no/m-sq

Crop yield, t/ha

Design of split - split plot design

experiment

Split

Number of main

treatment:

2

Number of sub

treatment:

5

Number of sub - sub

treatment:

2

Number of sub - sub -

sub treatment:

2

Number of replication:

Plot size:

3

Number of plots:

$40 \times 3 \mathrm{~m}$

120

The observations of different variables were made and analyzed using SAS statistical software.

\section{Results and Discussion}

The field performances of five combined tillage and seeding equipment were compared and analyzed for width of sowing, depth of slit cut, speed of operation, field capacity, field efficiency, fuel consumption, and wheel slip. Effect of tillage on cone index, plant emergence, plant population and grain yield of rice were compared and analyzed.

\section{Performance evaluation of combined tillage and seeding equipment}

\section{Width of seeding}

The effective width of sowing operation was measured and recorded for the five combined tillage and seeding equipment. The zero-tillslit drill covered $180 \mathrm{~cm}$ width whereas other drills namely zero-till, roto-till, strip-till and conventional seed drill covered $200 \mathrm{~cm}$ width in straw and non-straw fields for sowing of rice under wheeled area in irrigated and dry field conditions. In case of non-wheeled area, the effective width of seeding by zero-till-slit seed drill was measured to be $160 \mathrm{~cm}$ and other drills namely zero-till, roto-till, strip-till and conventional seed drill covered $180 \mathrm{~cm}$ width in straw and non-straw fields for rice seeding in irrigated and friable soil/dry field condition.

\section{Depth of seeding}

The depth of seeding were averaged for the two crop seasons for rice in Kharif 2007 and 2008 and plotted as shown in Figure 7 and 8 under control traffic and random traffic condition respectively. The depth of seeding in non-wheeled area was found higher compared to wheeled area in rice under control traffic and random traffic condition. The straw/non straw (A), combined tillage and seeding equipment (B), wheeled / non wheeled area (C) and irrigated and dry (D) 
conditions were found to be highly significant for depth of seeding at $5 \%$ and $01 \%$ level in rice under both control and random traffic condition.

\section{Speed of operation}

The speed of seeding operation were averaged for the two crop seasons for rice i.e. Kharif 2007 and 2008 as shown in Figure 9 and 10 under control traffic and random traffic condition respectively.. The data revealed that the speed of operation of zero-till-slit drill was comparatively higher compared to zerotill drill, roto-till drill and strip-till drill whereas values were more or less similar to conventional seed drill since the conventional seed drill was operated in prepared seedbed. Higher speed of operation was found to be in non-straw fields compared to straw fields in both rice under control traffic and random traffic condition. In rice crop under controlled traffic condition, the effects of combined tillage and seeding equipment (B) on speed of sowing operation (S) were found to be highly significant at $5 \%$ and $01 \%$ level. In rice under random traffic condition, the analysis of variance of factors $\mathrm{A}, \mathrm{B}, \mathrm{C}$ and $\mathrm{D}$; the two factor interactions of $A^{*} B, A^{*} D, B^{*} C$ and $\mathrm{B}^{*} \mathrm{D}$; three factor interaction of $\mathrm{A}^{*} \mathrm{~B} * \mathrm{D}$ and $A * C * D$ were found to be significant. The effects of irrigation / dry (D) condition on speed of sowing were found to be significant at $5 \%$ level in rice (CT).

\section{Field capacity}

The data of effective field capacity for seeding operation were averaged for the two crop seasons for rice i.e. Kharif 2007 and 2008 as shown in Figure 11 and 12 under control traffic and random traffic conditions respectively. The data and bar graphs indicated that the field capacity of zero-tillslit seed drill was found higher compared to zero-till, roto-till and strip-till seed drill and values were found comparable to conventional seed drill because the conventional seed drill was operated for preparatory seed bed.

Higher values of field capacity were found in non-straw fields compared to straw fields in rice under control and random traffic condition. In rice crop (CT), the analysis of variance of factors $\mathrm{A}, \mathrm{B}, \mathrm{C}, \mathrm{D}$; the two factor interaction of $A^{*} B, A^{*} D, B * C$ and $B^{*} D$; the three factor interaction of $A^{*} B^{*} C$ and $A^{*} B^{*} D$ on field capacity were found highly significant at $5 \%$ and $1 \%$ level. The three factor interaction of $\mathrm{B}^{*} \mathrm{C}^{*} \mathrm{D}$ was found significant at $5 \%$ level. In rice $(\mathrm{RT})$, the analysis of variance of factor $\mathrm{A}, \mathrm{B}, \mathrm{D}$; their two factor interaction of $A^{*} B, A^{*} C, B^{*} C$ and three factor interaction of $A^{*} B^{*} C$ on field capacity were found highly significant at $5 \%$ and $1 \%$ level. The analysis of variance of factor $\mathrm{C}$ and two factor interaction of $\mathrm{A} * \mathrm{D}$ and $B^{*} \mathrm{D}$ on field capacity were found to be significant at $5 \%$ level.

\section{Field efficiency}

Field efficiency (\%) was worked out for seeding and averaged for the two crop seasons; rice in Kharif 2007 and 2008 as shown in Figure 13 and 14 under control traffic and random traffic condition respectively.

The field efficiency (\%) for seeding was found to be higher in zero-till-slit seed drill compared to zero-till, roto-till and strip-till seed drill in both rice under control traffic and random traffic condition. The variation in field efficiencies of zero-till-slit seed drill and conventional seed drill was at par although conventional seed drill was operated in prepared seedbed. The field efficiency (\%) of five tillage and seeding equipment were found higher under non-straw condition compared to straw condition in rice under control traffic 
and random traffic conditions. In rice (CT), the analysis of variance factor A, B, D on field efficiency were found highly significant at $5 \%$ and $1 \%$ level.

The two factor interaction of $A * B, A * D, B * D$ and three factor interaction of $A^{*} B * D$ on field efficiency were found highly significant at 5 $\%$ and $1 \%$ level. In rice (RT), the analysis of variance of $\mathrm{A}, \mathrm{B}, \mathrm{C}$ and $\mathrm{D}$ on field efficiency were found highly significant at $5 \%$ and $1 \%$ level. The two factor interaction of $\mathrm{A}^{*} \mathrm{~B}$, $\mathrm{A}^{*} \mathrm{C}, \mathrm{B} * \mathrm{C}$ and three factor interaction of $\mathrm{A}^{*} \mathrm{~B} * \mathrm{C}$ on field efficiency were found highly significant at $5 \%$ and $1 \%$ level in rice (RT).

\section{Fuel consumption}

The fuel consumption (I/ha) for seeding were averaged for the crop seasons for rice in Kharif 2007 and 2008 as shown in Figure 15 and 16 under control traffic and random traffic condition respectively. The lower fuel consumption (I/ha) was obtained in zero-tillslit seed drill and conventional seed drill compared to zero-till, roto-till and strip-till seed drill in rice crop under control traffic and random traffic condition. Fuel consumption of tractor was found slightly higher in seeding operation by the five tillage and seeding equipment evaluated under irrigated condition.

Similarly, higher fuel consumption was found for sowing by five tillage and seeding equipment in wheeled area compared to nonwheeled area in rice under control traffic and random traffic condition.

In rice $(\mathrm{CT})$, the analysis of variance of factors $\mathrm{B}, \mathrm{C}, \mathrm{D}$ on fuel consumption were found to be highly significant at $5 \%$ and 01 $\%$ level. The two factor interaction of $\mathrm{A} * \mathrm{C}$, $\mathrm{A}^{*} \mathrm{D}$ and $\mathrm{B}^{*} \mathrm{D}$ on fuel consumption were found to be highly significant at $5 \%$ and 01 $\%$ level. In rice (RT), analysis of variance of factor $\mathrm{C}$ on fuel consumption was found to be significant at $5 \%$ level.

\section{Wheel slip}

The wheel slip (\%) of tractor for seeding were averaged for the two crop seasons for rice in Kharif 2007 and 2008 and plotted as shown in Figure 17 and 18 under control traffic and random traffic condition respectively. In rice, wheel slip (\%) was higher in straw fields compared to non-straw fields of irrigated and dry condition under control traffic and random traffic condition. Wheel slip (\%) was found to be lower in irrigated fields compared to dry fields in rice under wheeled area and non-wheeled area. The higher values of wheel slip (\%) were found in zero-till, roto-till and strip-till seed drill compared to the zero-tillslit and conventional seed drill for rice in wheeled area and non-wheeled area under control traffic and random traffic condition. The wheel slip (\%) has revealed that the little higher wheel slip occurred in control traffic compared to random traffic condition in rice.

In rice $(\mathrm{CT})$, the analysis of variance of factor $\mathrm{A}, \mathrm{B}, \mathrm{C}, \mathrm{D}$ and the two factor interaction of $A * B$ and $A * D$ on wheel slip were found to be highly significant at $5 \%$ and $1 \%$ level. In rice $(\mathrm{RT})$, the analysis of variance of $\mathrm{A}, \mathrm{B}, \mathrm{C}$, and $\mathrm{D}$; the two factor interaction of $\mathrm{A}^{*} \mathrm{~B}$, $\mathrm{A}^{*} \mathrm{D}, \mathrm{B} * \mathrm{C}, \mathrm{B} * \mathrm{D}$ and $\mathrm{C}^{*} \mathrm{D}$; the three factor interaction of $A * B * D$ and four factor interaction of $A * B * C * D$ on wheel slip were found to be highly significant at $5 \%$ and $1 \%$ level.

\section{Cone index}

The cone index $(\mathrm{kPa})$ at $25-100 \mathrm{~cm}$ depth of soil from experimental plots were averaged for the two crop seasons for rice in Kharif 2007 and 2008 under control traffic and random traffic condition respectively (Table 2 ). The cone index values were found to be higher in irrigated plots compared to dry plots 
in wheeled area and non-wheeled area in both rice under control traffic and random traffic condition.

The zero-till seeding plots showed higher values of cone index compared to other seeding techniques: zero-till-slit seeding, rototill seeding. strip-till seeding and conventional seeding in straw and non-straw fields in rice under control traffic and random traffic condition.

\section{Plant emergence count at 15 DAS}

The observed data of plant emergence count (no. $/ \mathrm{m}^{2}$ ) from experimental plots were averaged for the two crop seasons for rice i.e. Kharif 2007 and 2008 as shown in Figure 19 and 20 under control traffic and random traffic condition respectively.

Zero-till-slit seed drill and conventional seed drill gave little higher plant emergence count compared to zero-till, roto-till, and strip-till seed drill in both rice in irrigated and dry situations under control traffic and random traffic condition. In rice crop, both under CT and RT conditions, the analysis of variance for straw / without straw (A), and combined tillage and seeding equipment (B) on plant emergence were found to be highly significant and significant respectively.

\section{Plant population Count at 35 DAS}

The observed data of plant population count (no. $/ \mathrm{m}^{2}$ ) from experimental plots were averaged for the two crop seasons for rice in Kharif 2007 and 2008 as shown in Figure 21 and 22 under control traffic and random traffic condition respectively. The conventional seed drill gave higher plant population count followed by zero-till-slit seed drill, and lower in zero-till, roto-till and strip-till seed drill in rice in irrigated and dry fields under control traffic and random traffic condition. In rice (CT, the analysis of variance of factor $\mathrm{A}, \mathrm{B}, \mathrm{C}, \mathrm{D}$; the two factor interaction of $\mathrm{A}^{*} \mathrm{~B}, \mathrm{~A}^{*} \mathrm{C}, \mathrm{A}^{*} \mathrm{D}, \mathrm{B} * \mathrm{C}, \mathrm{C}^{*} \mathrm{D}$; three factor interaction of $A^{*} B^{*} D$ and four factor interaction of $A * B * C * D$ on plant population were found to be highly significant at $5 \%$ and $1 \%$ level. The two factor interaction of $\mathrm{B}^{*} \mathrm{D}$ and three factor interaction of $\mathrm{A}^{*} \mathrm{C} * \mathrm{D}$ on plant population were found significant at $5 \%$ level. In rice (CT), the analysis of variance for $\mathrm{A}, \mathrm{B}, \mathrm{C}, \mathrm{D}$; the two factor interaction of $\mathrm{A} * \mathrm{~B}, \mathrm{~A} * \mathrm{C}, \mathrm{A} * \mathrm{D} \mathrm{B} * \mathrm{D}$, $C^{*} \mathrm{D}$; three factor interaction of $\mathrm{A}^{*} \mathrm{~B} * \mathrm{D}$ and four factor interaction of $A^{*} B^{*} C^{*} D$ on plant population were found to be highly significant at $5 \%$ and $1 \%$ level. The three factor interaction of $\mathrm{A} * \mathrm{C} * \mathrm{D}$ on plant population was found significant at $5 \%$ level.

\section{Grain yield}

The observed data of grain yield (t/ha) from experimental plots were averaged for the two crop seasons for rice in Kharif 2007 and 2008 as shown in Figure 23 and 24 under control traffic and random traffic condition respectively. The plots in which sowing was done by zero-till-slit seed drill gave higher crop yields followed by zero-till seed drill and conventional seed drill in rice under control traffic and random traffic condition.

In rice $(\mathrm{CT})$, the analysis of variance of factor A, B, C, D on grain yield were found highly significant at $5 \%$ and $1 \%$ level. All the two factor; three factor and four factor interactions of A, B, C, and D on grain yield were found non-significant. In rice (RT), the analysis of variance of factor irrigated / dry field conditions (D) on grain yield was found highly significant at $5 \%$ and $1 \%$ level.

The analysis of variance of factor A, B and $\mathrm{C}$; the two factor interaction; three factor interaction and four factor interaction of $\mathrm{A}, \mathrm{B}$, $\mathrm{C}, \mathrm{D}$ on grain yield were found to be nonsignificant. 
Table.1 Specification of the direct drilling equipment used in field experiments

\begin{tabular}{|c|c|c|c|c|c|c|}
\hline S. No & Particulars & & ge and Seeding e & pment & & \\
\hline Name & of Seed drill & Zero-till-slit & Zero-till drill & Roto-till drill & Strip-till & Conventional- \\
\hline 1 & Working width, $\mathrm{cm}$ & 200 & $180-200$ & 200 & 200 & $180-200$ \\
\hline 2 & Row spacing, $\mathrm{cm}$ & 23 & $\begin{array}{l}18-20, \\
\text { (Adjustable) }\end{array}$ & $\begin{array}{l}18-20, \\
\text { (Adjustable) }\end{array}$ & 20, (Fixed) & $\begin{array}{l}18-20, \\
\text { (Adjustable) }\end{array}$ \\
\hline 3 & Furrow opener & $\begin{array}{l}\text { Rotary cutter } \\
\text { and narrow } \\
\text { shoe }\end{array}$ & $\begin{array}{l}\text { Inverted "T" and } \\
\text { narrow shoe }\end{array}$ & $\begin{array}{l}\text { Rotary blades } \\
\text { and shoe }\end{array}$ & $\begin{array}{l}\text { Rotary blades } \\
\text { and shoe }\end{array}$ & Shoe or shovel \\
\hline 4 & No of furrow openers & 9 & $9 / 11$ & $9 / 11$ & 9 & $9 / 11$ \\
\hline 5 & Drive wheel & $\begin{array}{l}\text { Peg type side } \\
\text { mounted }\end{array}$ & $\begin{array}{l}\text { Angle lug front } \\
\text { mounted }\end{array}$ & $\begin{array}{l}\text { Star lug rear } \\
\text { hinged }\end{array}$ & $\begin{array}{l}\text { Angle lug } \\
\text { side mounted }\end{array}$ & $\begin{array}{l}\text { Peg type side / } \\
\text { front mounted }\end{array}$ \\
\hline 6 & Weight, KN & 3000 & 2100 & 3500 & 3000 & 2500 \\
\hline 7 & Tractor Power $(\mathrm{kW})$ & 33.6 & $26.1-33.6$ & 33.6 & 33.6 & $26.1-33.6$ \\
\hline 8 & Unit Price, (Rs) & 1,65000 & 75,000 & $1,75,000$ & $1,70,000$ & 70,000 \\
\hline
\end{tabular}

Table.2 Average cone index $(\mathrm{kPa})$ at $25-100 \mathrm{~cm}$ depth of soil during seeding of different tillage and seeding equipment in rice

\begin{tabular}{|c|c|c|c|c|c|c|c|c|c|}
\hline \multirow{3}{*}{$\begin{array}{c}\text { Main } \\
\text { Treatment }\end{array}$} & \multirow[t]{3}{*}{ Sub Treatment } & \multicolumn{4}{|c|}{ Control Traffic } & \multicolumn{4}{|c|}{ Random Traffic } \\
\hline & & \multicolumn{2}{|c|}{ Wheeled Area } & \multicolumn{2}{|c|}{ Non-wheeled Area } & \multicolumn{2}{|c|}{ Wheeled Area } & \multicolumn{2}{|c|}{ Non-wheeled Area } \\
\hline & & Irrigated & Dry & Irrigated & Dry & Irrigated & Dry & Irrigated & Dry \\
\hline \multirow[t]{5}{*}{ Straw } & Slit - till drill & $92-291$ & $86-287$ & $63-269$ & $61-265$ & $92-293$ & $87-289$ & $62-68$ & $64-270$ \\
\hline & Zero - till drill & $103-299$ & $97-294$ & $70-271$ & $68-267$ & $103-99$ & $100-97$ & $64-74$ & $71-270$ \\
\hline & Roto - till drill & $99-299$ & $95-294$ & $67-273$ & $64-271$ & $101-01$ & $97-297$ & $65-63$ & $68-272$ \\
\hline & Strip - till drill & $101-299$ & $96-293$ & $71-273$ & $69-271$ & $102-02$ & $99-296$ & $66-65$ & $71-276$ \\
\hline & Conv. drill & $93-302$ & $87-287$ & $64-280$ & $61-276$ & $94-306$ & $90-290$ & $62-80$ & $64-279$ \\
\hline \multirow[t]{5}{*}{ No- straw } & Slit - till drill & $92-282$ & $87-277$ & $73-270$ & $72-267$ & $94-285$ & $91-280$ & $94-84$ & $76-268$ \\
\hline & Zero - till drill & $106-301$ & $101-296$ & $83-276$ & $79-273$ & $108-95$ & $102-99$ & $108-305$ & $81-277$ \\
\hline & Roto - till drill & $108-296$ & $103-293$ & $73-274$ & $70-272$ & $110-03$ & $103-95$ & $109-01$ & $75-276$ \\
\hline & Strip - till drill & $110-293$ & $102-286$ & $76-271$ & $74-267$ & $108-97$ & $105-90$ & $109-297$ & $77-272$ \\
\hline & Conv. drill & $106-299$ & $101-296$ & $66-286$ & $\begin{array}{l}100- \\
291\end{array}$ & $107-04$ & $103-98$ & $107-302$ & $\begin{array}{l}101- \\
294\end{array}$ \\
\hline
\end{tabular}

Fig.1 Developed rotary zero-till-slit seed cum fertilizer drill

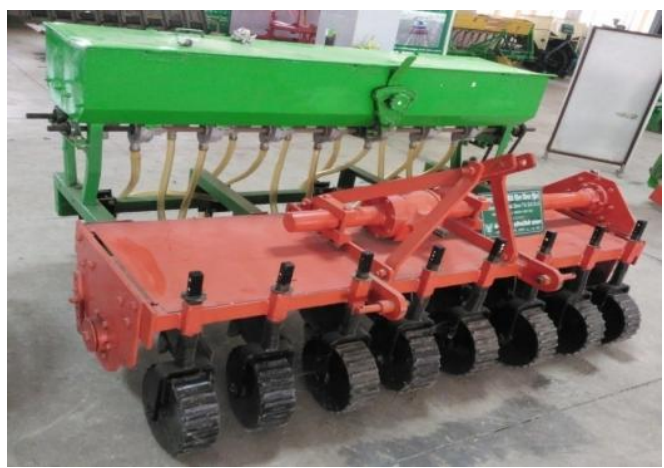


Fig.2 Slit cutters mounted on common shaft

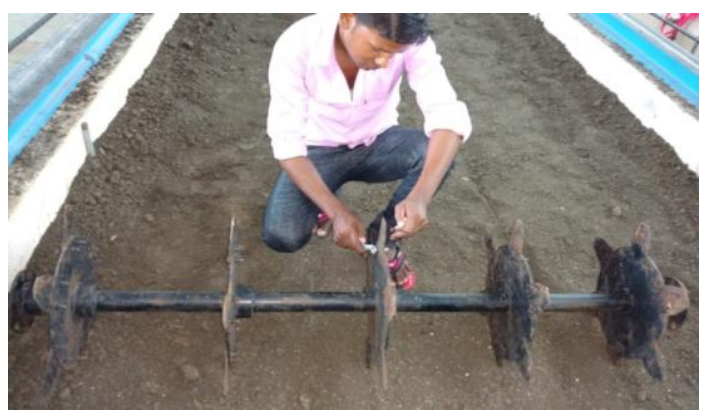

Fig.3 Zero-till seed cum fertilizer drill

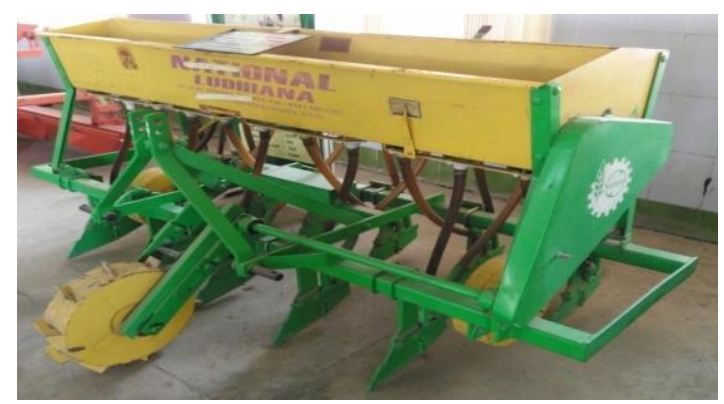

Fig.4 Roto-till seed cum fertilizer drill

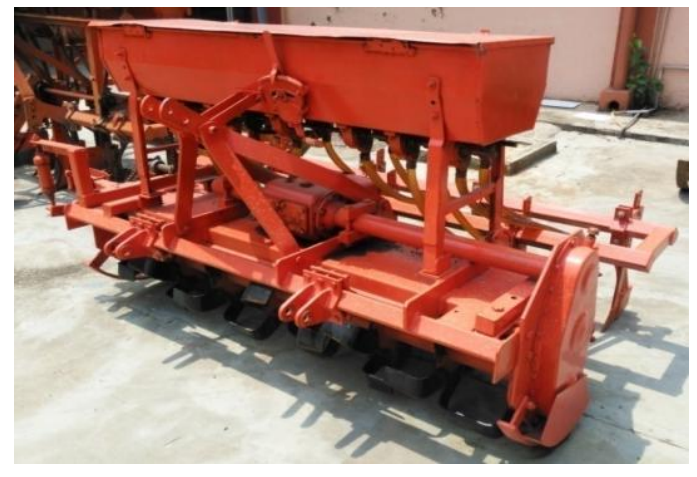

Fig.5 Strip-till seed cum fertilizer drill

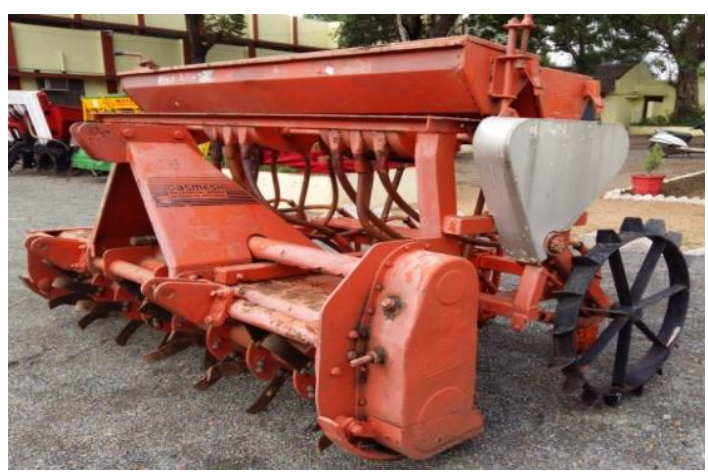


Fig.6 Improved seed cum fertilizer drill

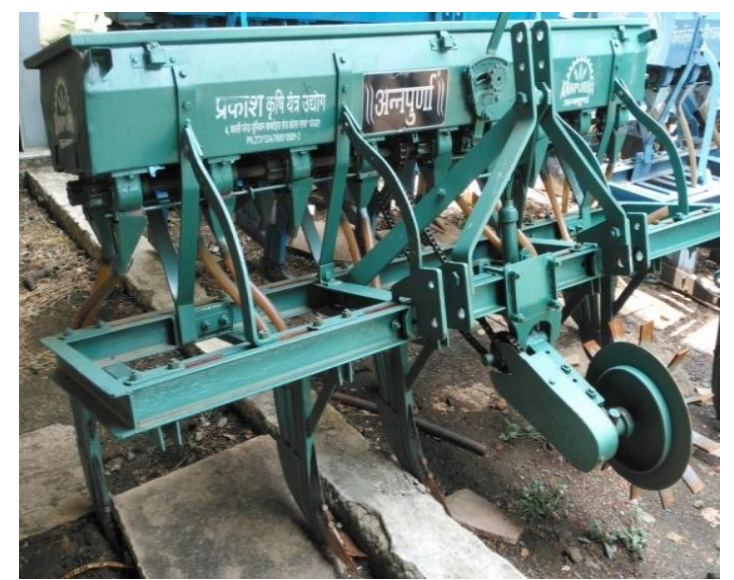

Fig.7 Depth of cut (mm) of different tillage cum seeding equipment in rice under control traffic condition

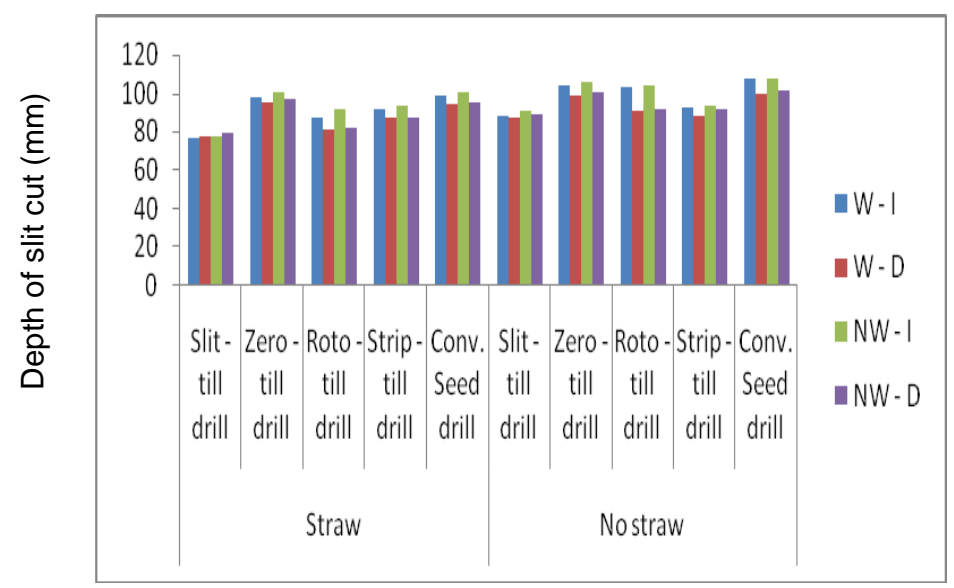

Fig.8 Depth of cut $(\mathrm{mm})$ of different tillage cum seeding equipment in rice under random traffic condition

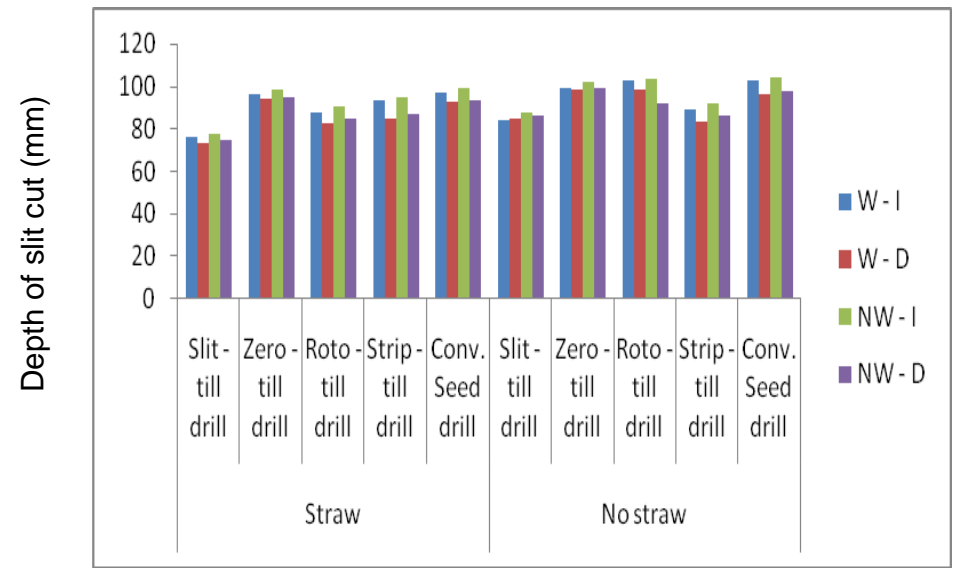


Fig.9 Speed of operation $(\mathrm{km} / \mathrm{h})$ of different tillage cum seeding equipment in rice under control traffic condition

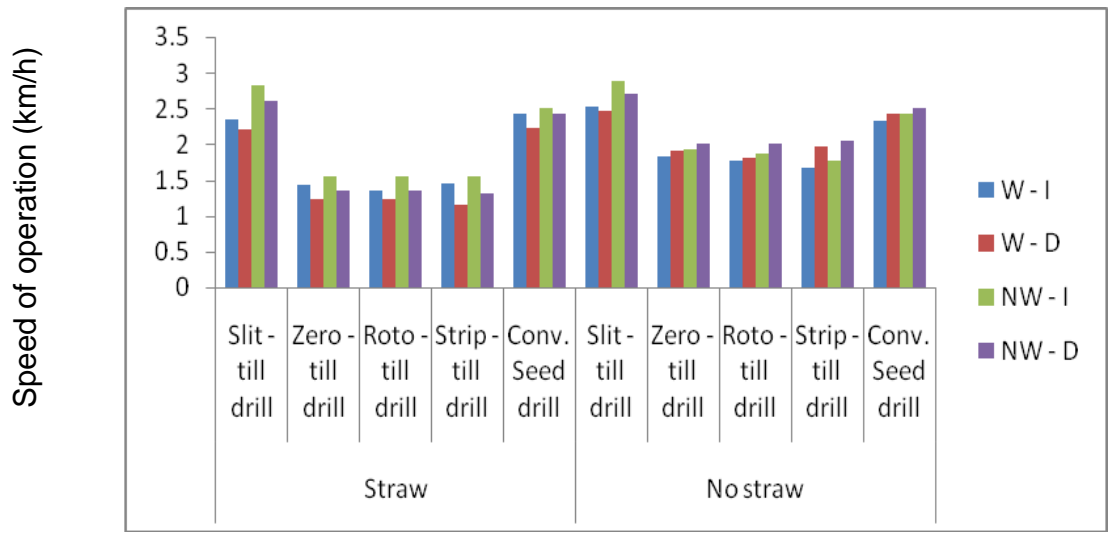

Fig.10 Speed of operation $(\mathrm{km} / \mathrm{h})$ of different tillage cum seeding equipment in rice under random traffic condition

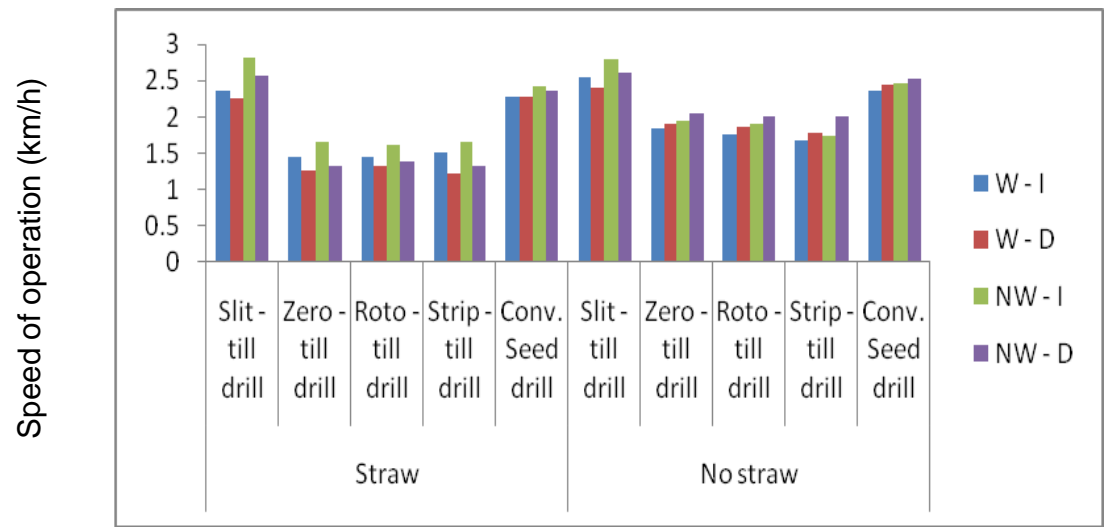

Fig.11 Field capacity (ha/h) of different tillage cum seeding equipment in rice crop under control traffic condition

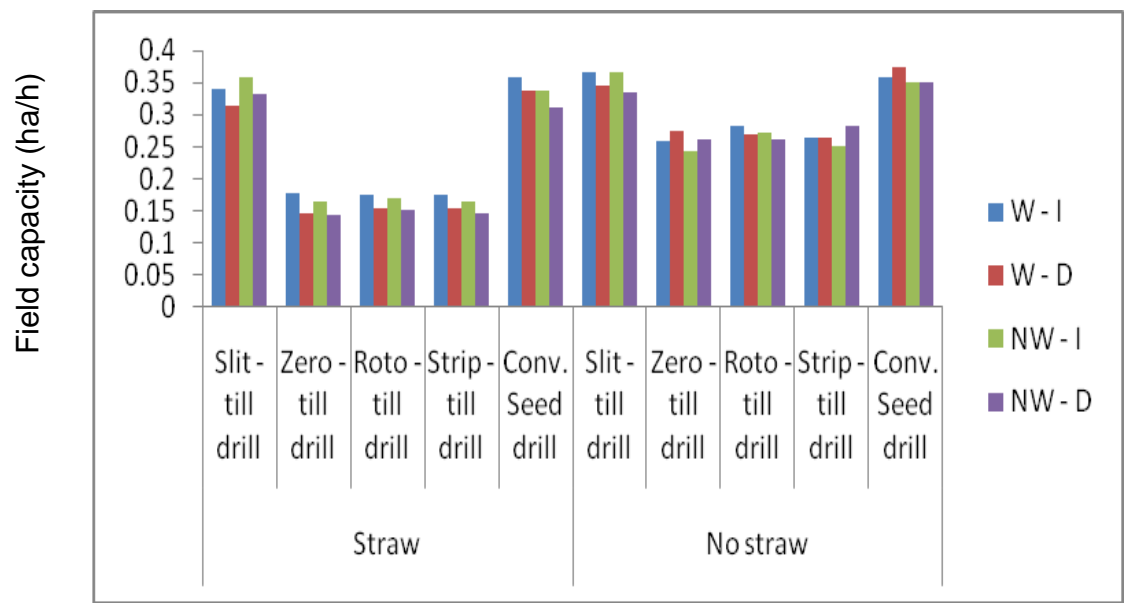


Fig.12 Field capacity (ha/h) of different tillage cum seeding equipment in rice crop under random traffic condition

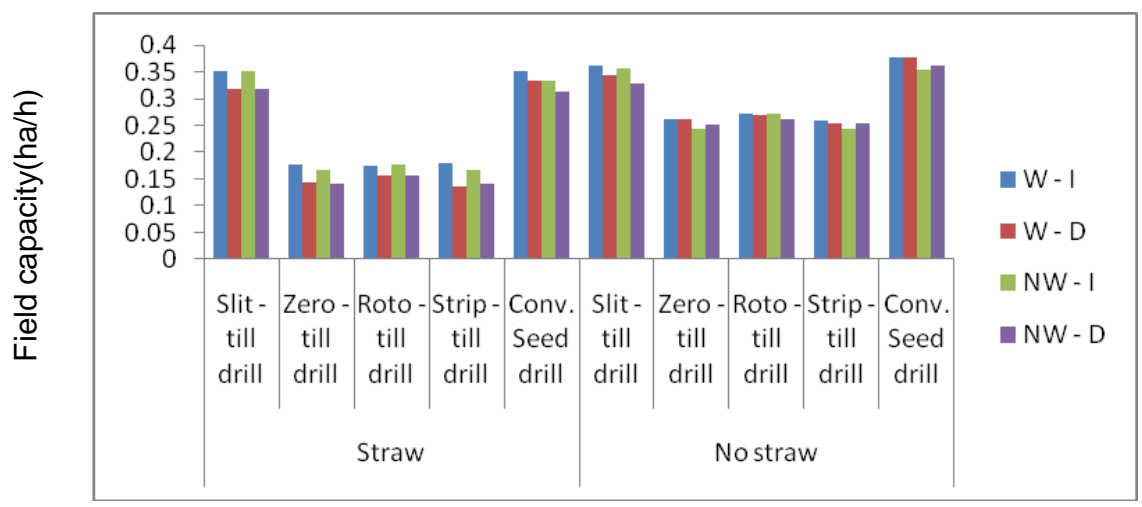

Fig.13 Field efficiency (\%) of different tillage cum seeding equipment in rice crop under control traffic condition

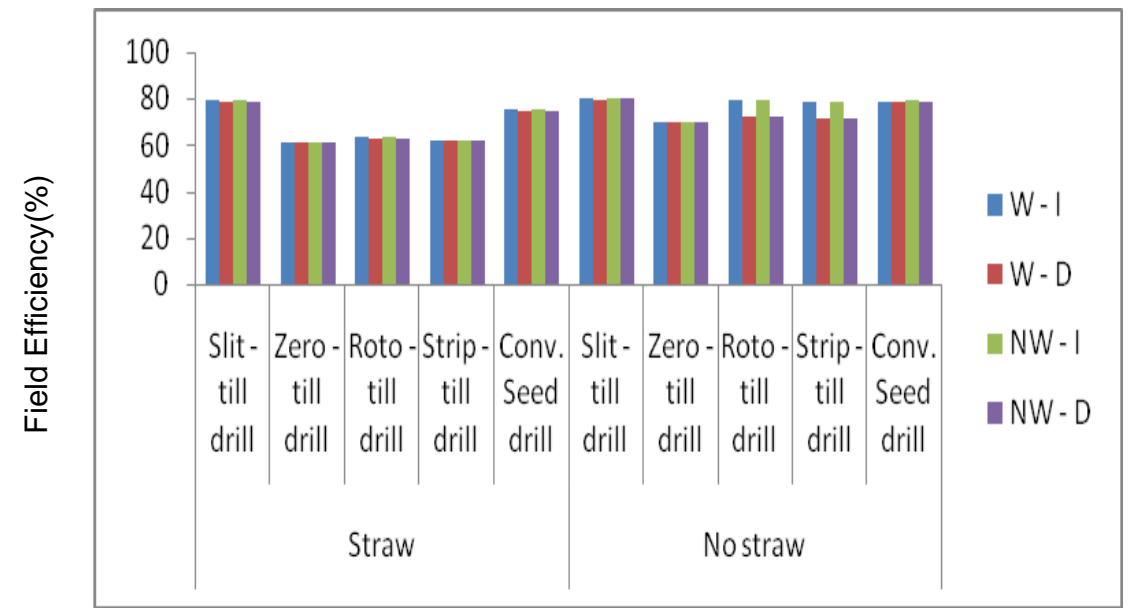

Fig.14 Field efficiency (\%) of different tillage cum seeding equipment in rice crop under random traffic condition

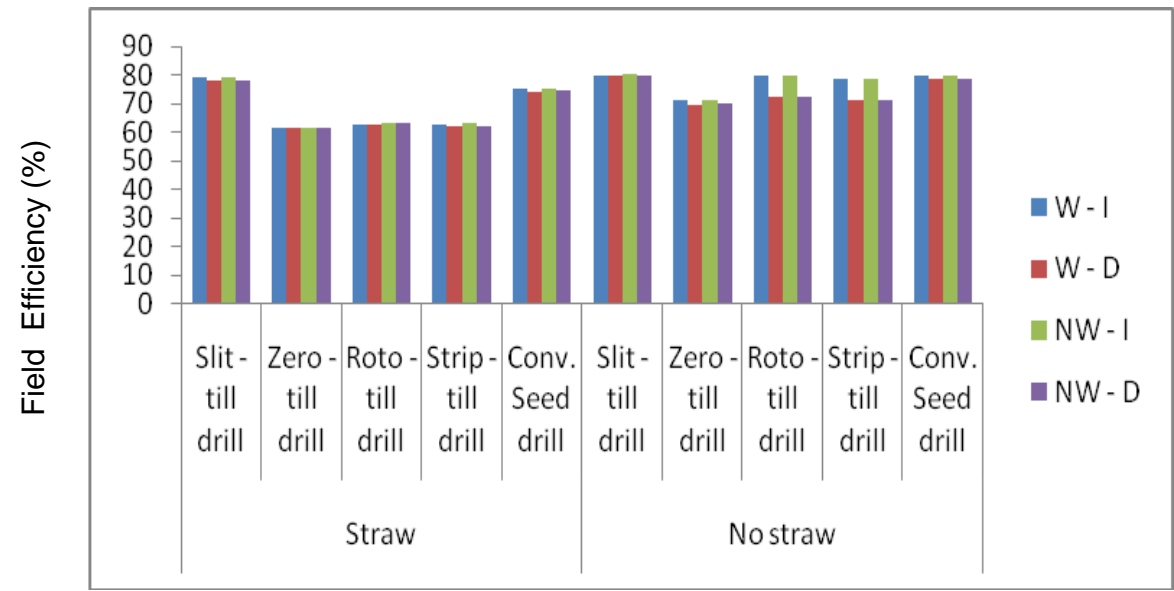


Fig.15 Fuel consumption $(1 / h)$ of different tillage cum seeding equipment in rice crop under control traffic condition

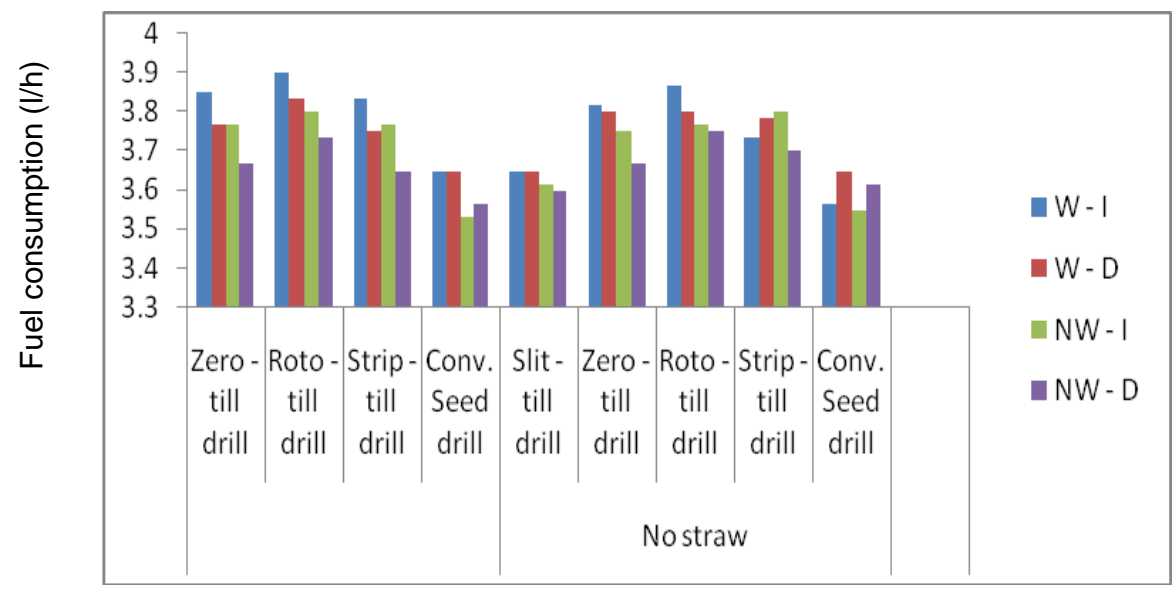

Fig.16 Fuel consumption $(1 / h)$ of different tillage cum seeding equipment in rice crop under random traffic condition

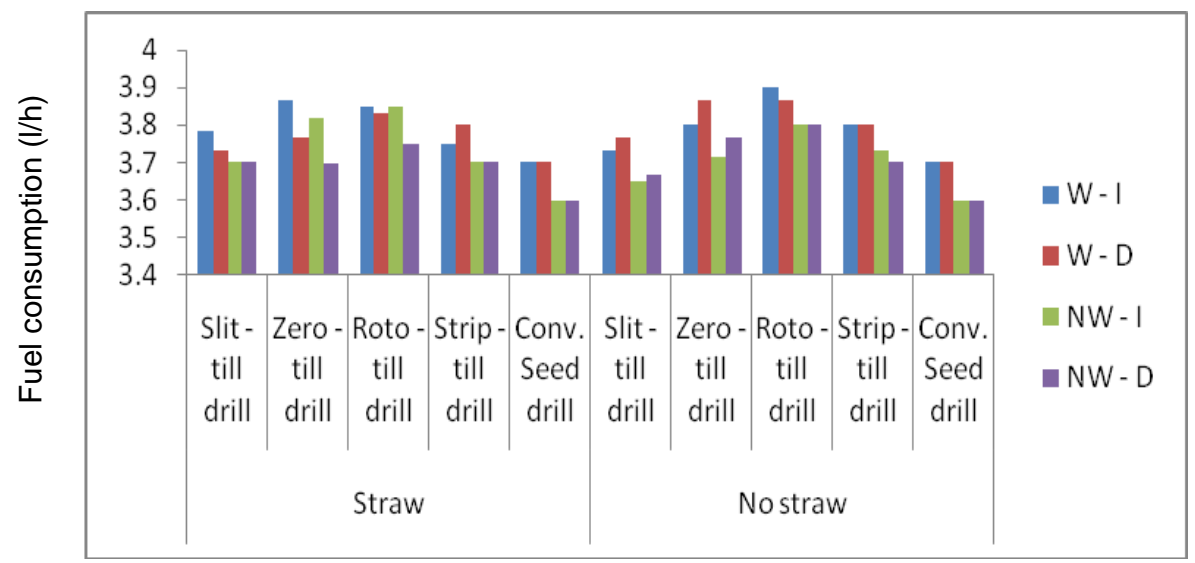

Fig.17 Wheel slip (\%) of different tillage cum seeding equipment in rice crop under control traffic condition

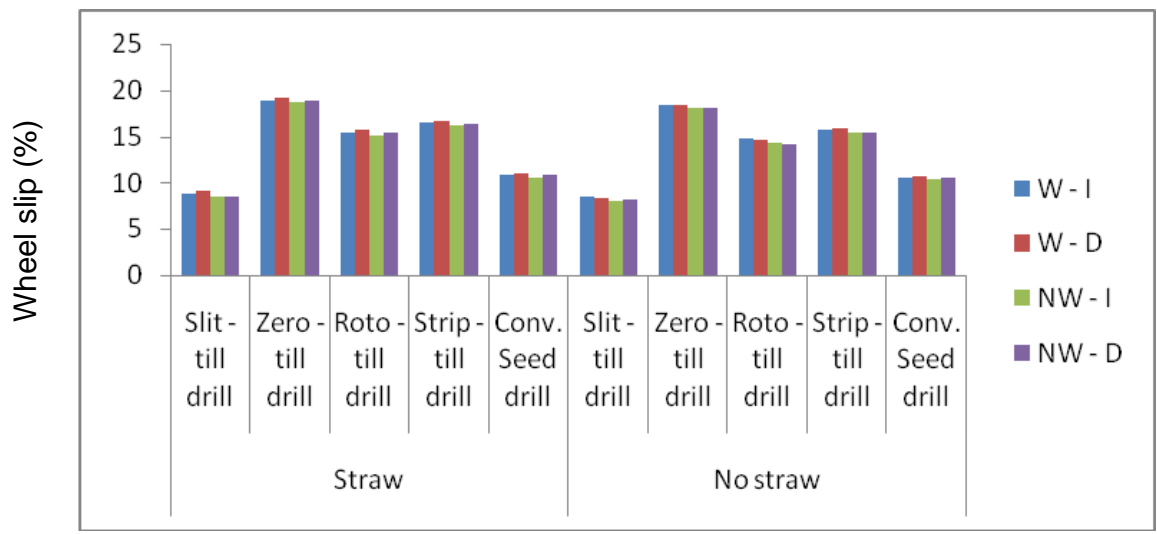


Fig.18 Wheel slip (\%) of different tillage cum seeding equipment in rice crop under random traffic condition

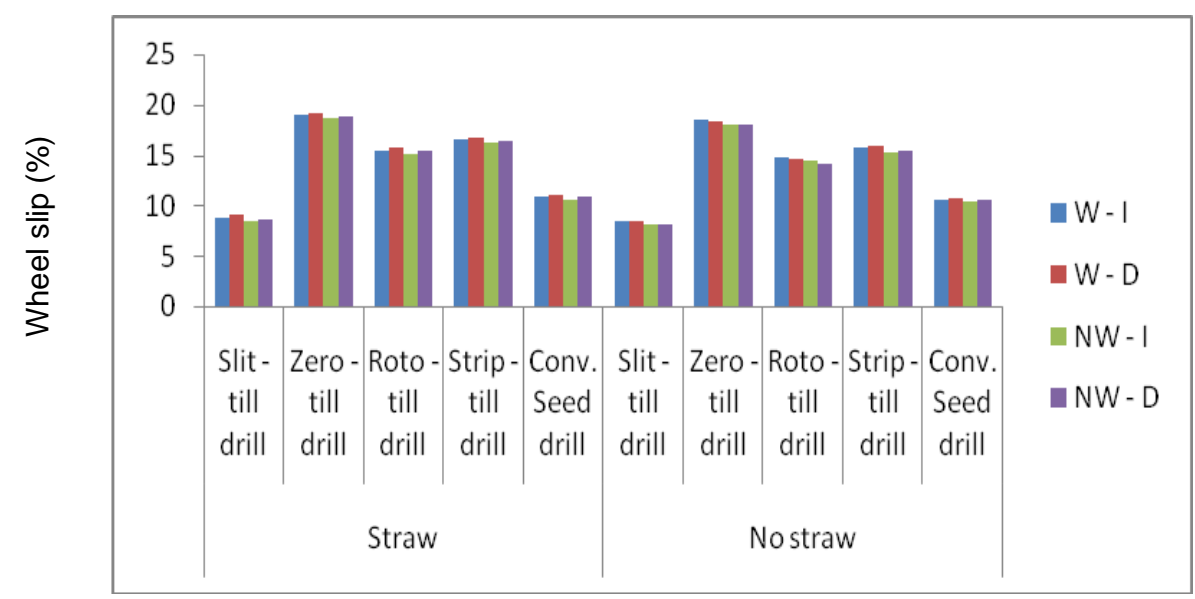

Fig.19 Plant emergence at $15 \mathrm{DAS}\left(\right.$ no. $\left./ \mathrm{m}^{2}\right)$ of different tillage cum seeding equipment in rice crop under control traffic condition

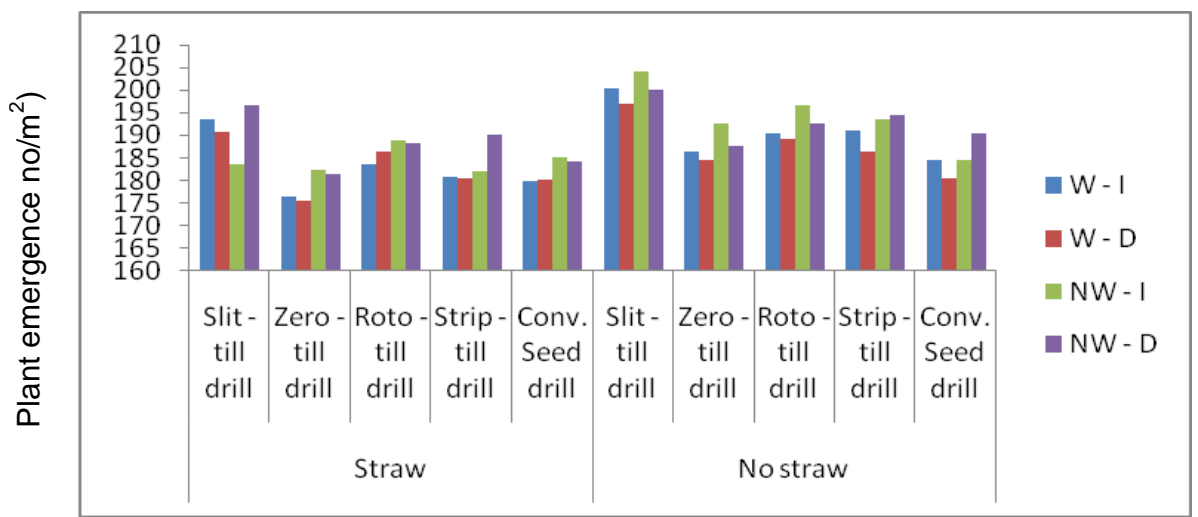

Fig.20 Plant emergence at $15 \mathrm{DAS}\left(\right.$ no. $\left./ \mathrm{m}^{2}\right)$ of different tillage cum seeding equipment in rice crop under random traffic condition

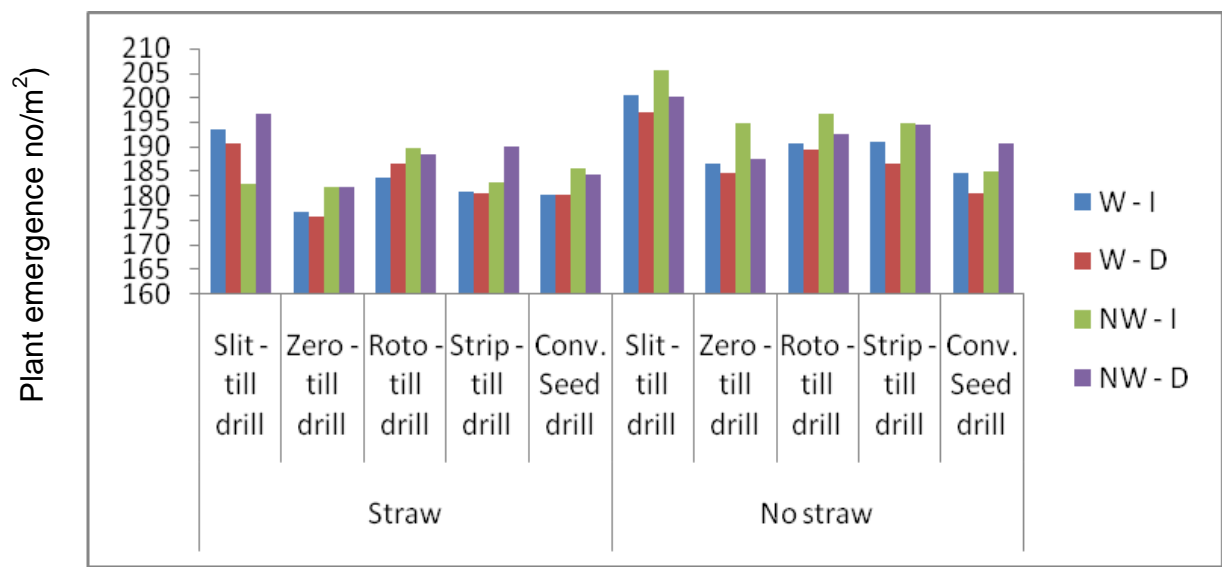


Fig.21 Plant population at 35 DAS (no./sq.m) of different tillage cum seeding equipment in rice crop under control traffic condition

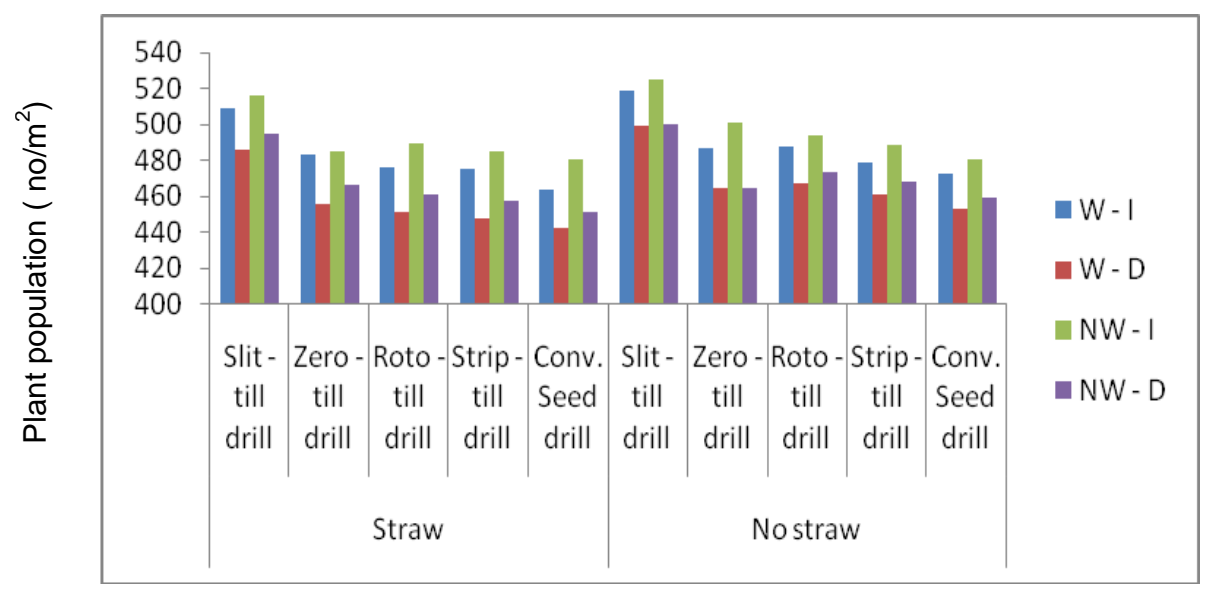

Fig.22 Plant population at $35 \mathrm{DAS}\left(\right.$ no. $\left./ \mathrm{m}^{2}\right)$ of different tillage cum seeding equipment in rice crop under random traffic condition

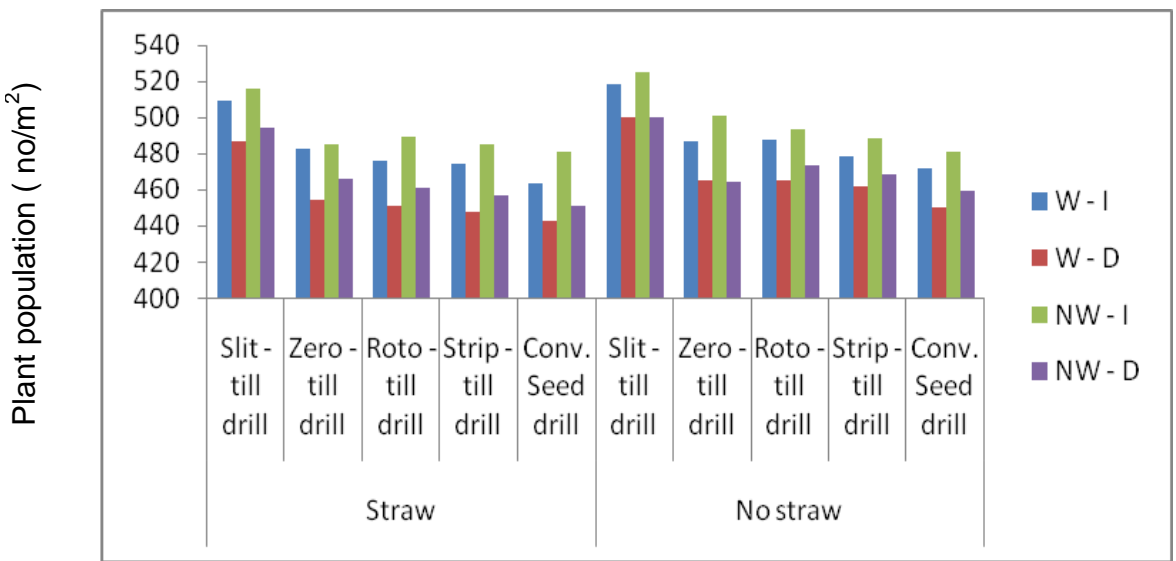

Fig.23 Grain yield (t/ha) in different tillage cum seeding equipment in rice crop under control traffic condition

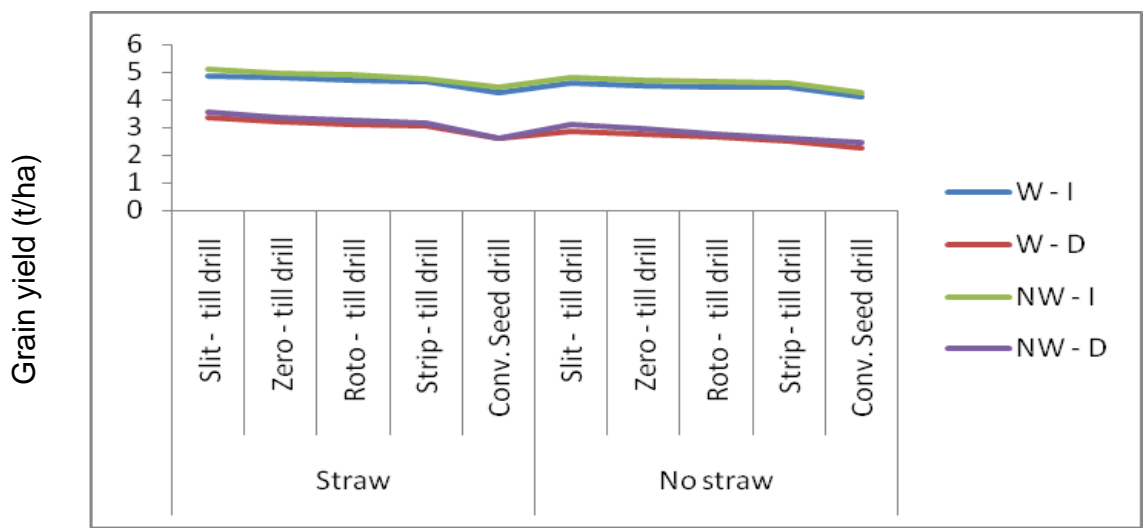


Fig.24 Grain yield (t/ha) in different tillage cum seeding equipment in rice crop under random traffic condition

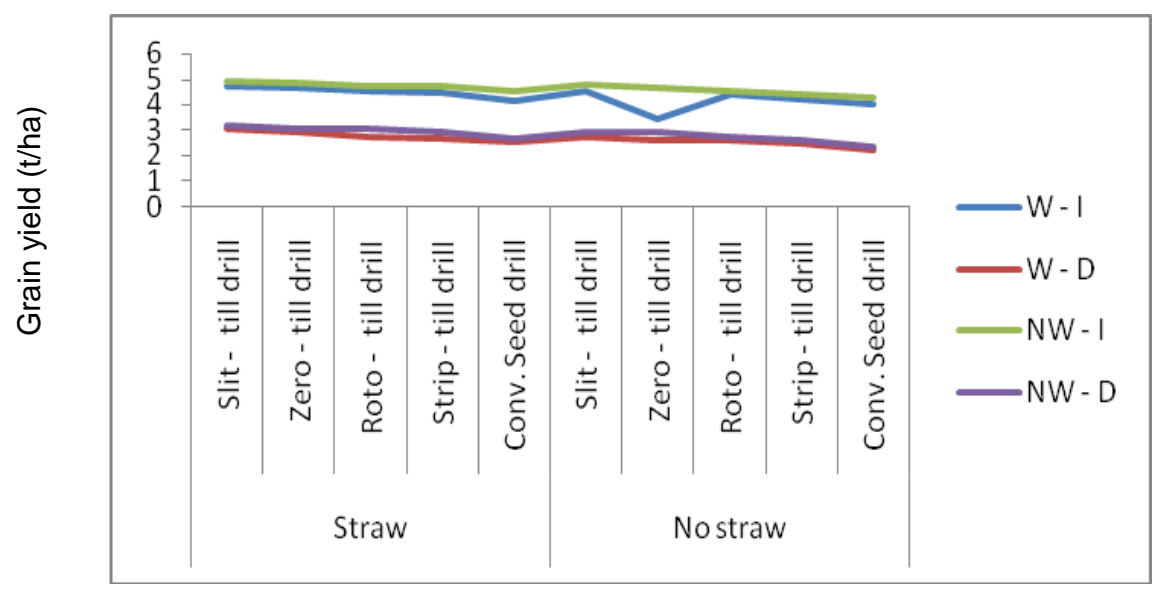

Conclusions are as follows

Depth of sowing in non-wheeled area was, found to be higher compared to wheeled area in all the combined tillage and seeding equipment in rice under controlled traffic and random traffic condition.

Zero-till-slit seed drill showed higher speed of seeding, field capacity, field efficiency with lower fuel consumption and wheel slip under controlled traffic, in straw and non-straw fields, compared to random traffic.

The higher speed of operation, field capacity and field efficiency were found to be in zero-till-slit seed drill compared to zerotill, roto-till, strip-till seed drills whereas the values were at par with the conventional seed drill in rice under CT and RT condition.

Lower values of speed of operation, field capacity and field efficiency in all the combined tillage and seeding equipment were found in straw covered fields compared to non straw fields in rice under CT and RT condition.

Lower fuel consumption rates were found to be in zero-till-slit seed drill and conventional seed drill compared to zero-till, roto-till, and strip-till seed drill in rice under both $\mathrm{CT}$ and $\mathrm{RT}$ condition.

Fuel consumption for tractor sowing by five tillage and seeding equipment were found to be higher in irrigated fields compared to dry fields in rice and wheat crops under both $\mathrm{CT}$ and RT condition.

Wheel slip values were found to be higher in straw fields compared to non-straw fields in rice under $\mathrm{CT}$ and $\mathrm{RT}$ condition.

The values of wheel slip were found to be higher in controlled traffic compared to random traffic condition in rice.

The lower values of wheel slip in wheeled and non-wheeled areas were found in zero-till-slit seed drill compared to zerotill, roto-till, strip-till and conventional seed drills in rice under $\mathrm{CT}$ and $\mathrm{RT}$ conditions.

Wheel slip were found lower in irrigated fields compared to dry fields in rice in wheeled and non-wheeled areas under $\mathrm{CT}$ and RT condition.

Cone index were found higher in irrigated fields as compared to dry fields in wheeled and non-wheeled area of rice under CT and RT condition.

The zero-till seed drill plots were found to be having higher values of cone index compared to the plots sown by other tested combined tillage and seeding 
equipment in straw / non straw fields of rice under $\mathrm{CT}$ and $\mathrm{RT}$ condition.

Higher plant emergence count were found in plots sown by zero-till-slit seed drill and conventional seed drill under irrigated and dry condition compared to zero-till, roto-till and strip-till seed drill in rice under CT and RT condition.

The conventional seed drill gave higher plant population count at 35 DAS followed by zero-till-slit drill and lower in zerotill, roto-till and strip-till drill in rice in irrigated and dry fields under CT and RT condition.

Higher crop yields were achieved in rice sown by zero-till-slit seed drill followed by zero-till and conventional seed drill under CT and RT condition.

Controlled traffic zero-till-slit drilling of seeds in straw covered fields gave higher grain yields in rice compared to the zero-till, roto-till, strip-till and improved conventional seed drills. Similar advantages were also found in non-straw fields.

The lower grain yields were found in wheeled area compared to non-wheeled area in straw fields under random traffic condition.

\section{Acknowledgement}

Sincere acknowledgment are due to JNKVV, Jabalpur and (CIAE-ICAR), Bhopal to extend their facilities required for the studies further.

Sincere acknowledgment is due to IGKV, Raipur for their kind permission to Mohd. Quasim to pursue the Ph.D. Studies.

\section{References}

Anonymous, 2002. The conservation agriculture working group activities 2000-2001. Food and Agriculture Organization of the United Nations,
Rome, $25 \mathrm{pp}$.

Anonymous. 2004. Conservation agriculture for sustainable crop production in northern Kazakhstan. Final Report of project (TCP/KAZ/2801, T) for 20022004. FAO, Ministry of Agriculture of the Republic of Kazakhstan, CIMMYT, and the Union of Farmers of Kazakhstan.

Guérif, J., Richard G, Dürr C, Machet JM, Recous S and Roger EJ. (2001). A review of tillage effects on crop residue management, seed bed conditions and seedling establishment, Soil and Tillage Res., 61: 13-32.

Rautaray, SK., 2007. Machinery for conservation agriculture: Progress and needs, Paper in the book "Conservation Agriculture - Status and Prospects" (Edrs. Abrol, I.P. et al.) CASA, New Delhi, pp. 43-49.

Riley, H., Borresen T, Ekeberg E and Rydberg T. 1994. Trends in reduced tillage research and practice in Scandinavia. In: Carter, M.R. (ed.) Conservation tillage in temperature agro-ecosystems. Lewis, Boca Raton, pp. 23-45.

Shukla, LN., Sidhu HS and Bector V. 2003. Development of commercial prototype of direct drilling machine with. notched-double disc furrow openers. Agricultural Engineering Today, 27(56): 8-17.

Shumba, E., Waddington S and Rukuni M. 1989. Delayed maize plantings in a smallholder farming area of Zimbabwe: Problem diagnosis. J. Agric. Res., 27: 103-112, 1989.

Shumba, E., Waddington S and Rukuni M. 1992. Use of tine-tillage, with atrazine weed control, to permit earlier planting of maize by smallholder farmers in Zimbabwe. Experimental Agriculture, 28: 443-452.

Solie, J., and Pepper TF. 1989. Drill selection 
for seeding wheat after herbicide incorporation. Trans of ASAE, 32(5): 1534-1538.

Rautary, S.K., 2008. Personal discussion and interaction on different design parameters of slit cutters for seeding on unploughed soil.

Quasim, M., 2016. Study of Resource Conservation technologies and development of combined tillage and seeding equipment, unpublished Ph.D. thesis, JNKVV, Jabalpur, M.P.

\section{How to cite this article:}

Mohammad Quasim, A.K. Shrivastava, S.K. Rautaray and Avinash Kumar Gautam. 2019. Comparative Evaluation of Zero-till-slit Seed Drill and Combined Tillage and Seeding Equipment in Rice. Int.J.Curr.Microbiol.App.Sci. 8(06): 132-149. doi: https://doi.org/10.20546/ijcmas.2019.806.018 